\title{
Perbandingan analisis nilai tambah produk Pisang Sale Kering dan Pisang Sale Basah pada usaha tradisional Red Golden desa Deyah Raya kecamatan Syiah Kuala kota Banda Aceh
}

\author{
Chairuni AR \\ Fakultas Teknologi Pertanian, Universitas Serambi Mekkah, Indonesia \\ Korespondensi: chairuni@serambimekkah.ac.id
}

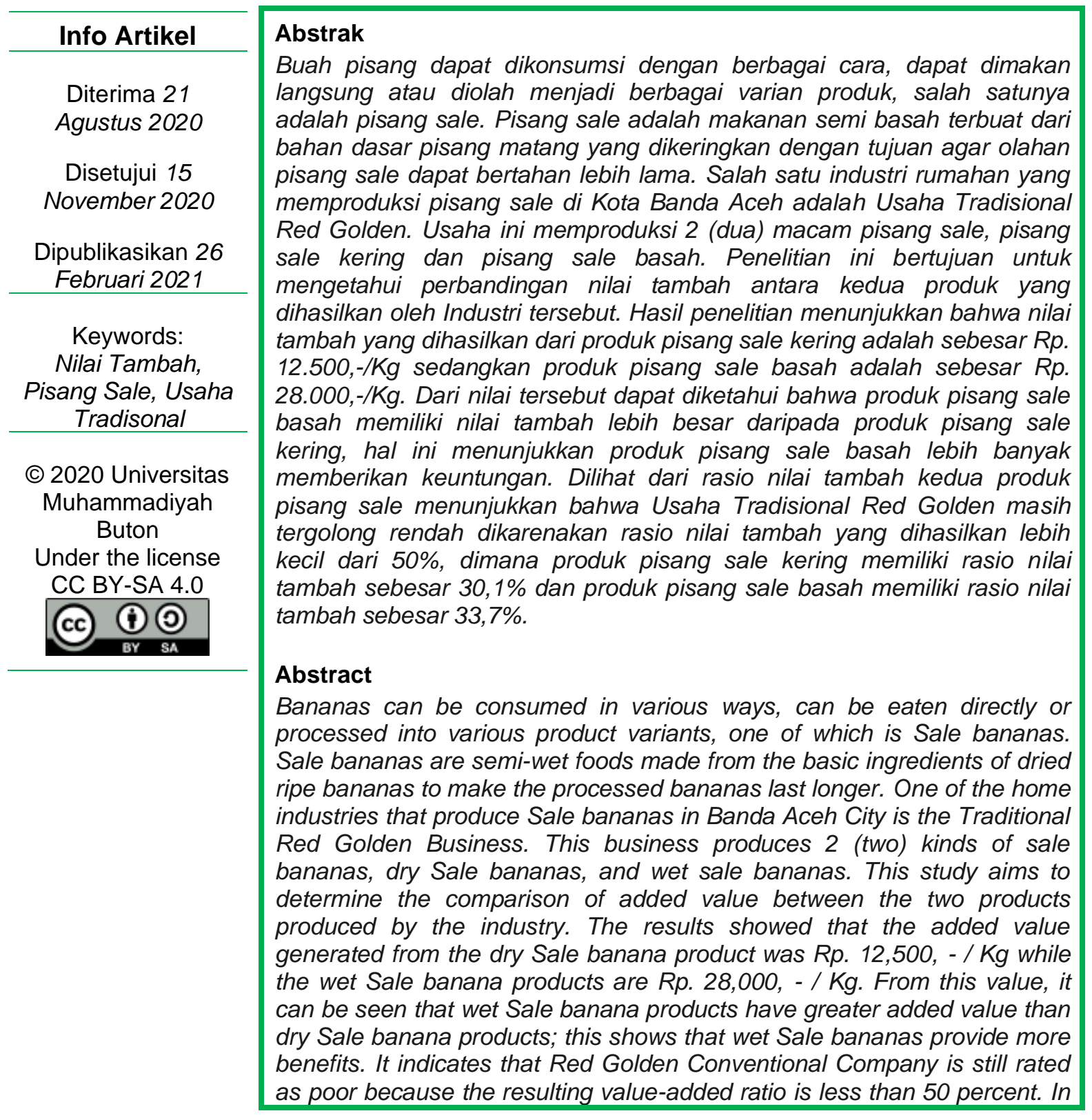


comparison, the dry Selling banana has a value-added ratio of 30.1 percent, and the wet Sale banana has a value added ratio of 33.7 percent, depending on the added value ratio of the two sales banana products. Keywords: Value Added; Banana Sale; Traditional Business

\section{Pendahuluan}

Produk pisang sale merupakan produk yang dihasilkan dari pengolahan pisang menjadi pisang sale. Pisang adalah salah satu hasil pertanian yang jumlahnya melimpah di Indonesia, hal tersebut dikarenakan batang pisang dapat tumbuh hampir di seluruh wilayah Indonesia. Luas pengusahaan pisang rakyat di Provinsi Aceh berkisar antara 0,5 ha sampai 2,0 ha. Pola pengusahaannya adalah sistem campuran/tumpangsari dengan tanaman keras dan buah-buahan. Jenisjenis pisang yang banyak ditanam adalah pisang ayam (barangan), kepok, wak, ambon, raja, mas, abin, susu dan tanduk. Diantara jenis-jenis pisang ini, pisang ayam yang paling banyak ditanam karena harganya lebih tinggi dibanding jenis pisang lain dan merupakan pisang meja di restoran/ rumah-rumah makan. Sedangkan pisang yang paling rendah harganya adalah pisang wak dan biasanya digunakan sebagai pisang olahan (keripik/ sale)

Buah pisang dapat dikonsumsi dengan berbagai cara dan dengan tahapan pengolahan yang mudah, buah pisang dapat dimakan secara langsung hingga diolah menjadi berbagai macam produk makanan yang menarik dan enak, salah satunya adalah pisang sale. Pisang sale merupakan salah satu produk olahan yang disukai oleh hampir semua lapisan masyarakat karena rasanya yang manis dan gurih sehingga cocok dijadikan sebagai hidangan cemilan dan juga banyak dibeli masyarakat untuk oleh-oleh.

Produk pisang sale merupakan makanan semi basah yang dibuat dari pisang matang dengan cara pengeringan dan pengasapan dan juga tanpa penambahan pengawet. Tujuan pengeringan tersebut adalah untuk mengurangi kadar air dalam buah pisang hingga kadar airnya mencapai $15-20 \%$ dengan begitu masa penyimpanan produk pisang sale dapat lebih lama. Pisang sale mempunyai cita rasa yang khas dan daya simpan yang cukup lama. Pisang sale yang diberi tepung dan digoreng bisa disebut pisang sale kering, sangatlah enak untuk makanan cemilan yang dihidangkan bersama teh hangat dan kopi. Pisang sale juga dapat digunakan untuk pelengkap dalam pembuatan aneka kue seperti cake, kue kering dan lain sebagainya (Hapsoro \& Yusnita, 2018). Komoditi pisang sale di Kota Banda Aceh selain untuk konsumsi lokal, pisang juga menjadi incaran para pengrajin pisang sale, keripik dan industri pengolahan pisang lainnya.

Pengolahan buah pisang menjadi sale pisang yang ada di Banda Aceh adalah Pabrik Pisang Sale Red Golden terletak di Desa Deyah Raya Kecamatan Syiah Kuala Kota Banda Aceh. Pabrik Pisang Sale Red Golden, Desa Deyah Rayah Kecamatan Syiah Kuala Kota Banda Aceh mengolah buah pisang menjadi produk pisang sale dikarenakan ketersediaan bahan baku pisang kepok yang harganya murah dan melimpah, dan juga ingin menciptakan lapangan pekerjaan.

Mainura (2014) telah melakukan penelitian tentang analisis nilai tambah dan sistem pemasaran pisang sale di kecamatan Langkahan Kabupaten Aceh Utara. Berdasarkan hasil analisis nilai tambah kegiatan pengolahan pisang sale di kecamatan Langkahan Kabupaten Aceh Utara memberikan nilai tambah yang positif terhadap peningkatan pendapatan para pengrajin, hal ini dibuktikan bahwa 
dalam setiap $1 \mathrm{~kg}$ penggunaan bahan baku pisang memberikan nilai tambah bagi produk pisang sale yang dihasilkan, yaitu sebesar Rp. 3.106,23/kg atau dalam persentasenya adalah $22,32 \%$.

Nilai tambah (value added) adalah pertambahan nilai suatu komoditas karena mengalami proses pengolahan, pengangkutan ataupun penyimpanan dalam suatu produksi. Dalam proses pengolahan nilai tambah dapat didefinisikan sebagai selisih antara nilai produk dengan nilai biaya bahan baku dan input lainnya, tidak termasuk tenaga kerja. Sedangkan marjin adalah selisih antara nilai produk dengan harga bahan bakunya saja. Dalam marjin ini tercakup komponen faktor produksi yang digunakan yaitu tenaga kerja, input lainnya dan balas jasa pengusaha pengolahan (Hayami et al, 1987).

Hasanah, Uswatun, \& Dkk (2015) juga telah melakukan penelitian tentang Analisis Nilai Tambah Agroindustri Sale Pisang di Kabupaten Kebumen. Hasil penelitian menunjukkan bahwa ukuran pisang raja siam yang digunakan tidak menghasilkan nilai tambah yang berbeda metode membuat kerekel sale cara pasahan dan cara pres tidak menghasilkan nilai tambah yang berbeda pengusaha murni mampu menciptakan nilai tambah lebih besar dibandingkan petani pengrajin sale pisang, pengusaha yang membeli kerekel sale mampu menciptakan nilai tambah lebih besar dibandingkan dengan yang membuat kerekel sendiri, faktorfaktor yang berpengaruh terhadap produksi sale pisang adalah jumlah modal dan jumlah pisang.

Adanya kegiatan pengolahan pisang sale ini akan memberikan nilai tambah karena dikeluarkannya biaya-biaya sehingga terbentuk harga baru produk yang lebih tinggi dan keuntungan yang lebih besar. Hal ini juga untuk membandingkan antara kedua produk yaitu pisang sale kering dengan pisang sale basah. Analisis nilai tambah diperlukan untuk mengetahui besarnya nilai tambah yang diberikan oleh kedua produk pisang sale sebagai bahan baku sehingga bisa diketahui apakah usaha yang dijalankan tersebut efisien dan produk manakah yang memberikan keuntungan lebih besar kepada Usaha Tradisional Red Golden.

Berdasarkan uraian tersebut permasalahan yang dapat dirumuskan dalam penelitian ini yaitu: (1) bagaimana proses pengolahan pisang menjadi produk pisang sale kering dan pisang sale basah pada Usaha Tradisional Red Golden; (2) berapakah nilai tambah yang dihasilkan dari masing-masing produk pisang sale kering dan pisang sale basah.

Berdasarkan rumusan masalah tersebut maka tujuan penelitian ini adalah untuk mengetahui proses pengolahan pisang menjadi pisang sale kering dan pisang sale basah. Dan untuk menghitung dan menganalisis besarnya nilai tambah yang dihasilkan dari masing-masing produk pisang sale baik pisang sale kering maupun pisang sale basah pada Usaha Tradisional Red Golden di Desa Deyah Raya Kecamatan Syiah Kuala Kota Banda Aceh.

\section{Metode}

\subsection{Metode Pengumpulan Data}

Metode pengumpulan data yang digunakan dalam penelitian ini ada 3 (tiga) macam antara lain sebagai berikut. 
1. Metode wawancara, dimana pada metode pengambilan data dilakukan dengan wawancara secara luas dan mendalam kepada responden dengan menggunakan daftar pertanyaan (kuesioner) yang telah dipersiapkan oleh peneliti.

2. Metode observasi, dimana pada metode pengumpulan data ini dilakukan dengan cara melakukan pengamatan langsung dengan objek yang akan diteliti sehingga didapatkan gambaran yang jelas mengenai objek yang akan diteliti.

3. Metode pencatatan, dimana metode pengumpulan data dengan cara melakukan pencatatan data dari segala sumber yang berkaitan dengan penelitian. Jenis data yang digunakan dalam penelitian ini yaitu data primer dan data sekunder, adapun penjelasannya sebagai berikut :

a. Data primer adalah data yang dikumpulkan dan diperoleh langsung dari pemilik Usaha Tradisional Red Golden dan pihak-pihak yang terkait dengan menggunakan daftar pertanyaan yang sudah dipersiapkan sebelumnya. Data profil usaha, pengadaan bahan baku, modal, biaya produksi, proses pengolahan hingga pemasaran, dan pendapatan diperoleh melalui wawancara kepada pemilik Usaha Tradisional Red Goden dengan menggunakan panduan kuesioner.

b. Data sekunder berupa gambaran umum wilayah penelitian, letak geografis, data topografi, suhu, dan kependudukan diperoleh dari BPS Kota Banda Aceh dan Dinas Pertanian Pangan Provinsi Aceh. Data pendukung lainnya diperoleh dari internet, berbagai buku, jurnal, dan literatur yang berkaitan dengan penelitian ini.

\subsection{Metode Analisis Data}

Metode analisis data adalah deskriptif. Data kuantitatif meliputi perhitungan analisis pendapatan dan keuntungan, nilai tambah dihitung secara kuantitatif dengan menggunakan metode Hayami (1987).

Pengolahan dalam penelitian ini menggunakan metode (Hayami, 1987). Alasan digunakannya metode tersebut dalam penelitian ini adalah (1) metode Hayami (1987) dapat digunakan untuk proses pengolahan produk pertanian; (2) dengan Metode Hayami (1987), selain nilai tambah dan nilai output juga dapat diketahui besarnya balas jasa terhadap pemilik-pemilik faktor-faktor produksi yaitu tenaga kerja, sumbangan input lain, dan keuntungan.

Untuk melihat berapa besar nilai tambah dari proses pengolahan pisang sampai menjadi pisang sale maka digunakan rumus perhitungan nilai tambah dari metode (Hayami, 1987), yaitu:

$$
\begin{aligned}
& \text { NT }=\text { NP }-(\mathrm{NBB}+\mathrm{NBP}) \\
& \text { Keterangan }: \\
& \mathrm{NT} \quad=\text { Nilai Tambah }(\mathrm{Rp} / \mathrm{Kg}) \\
& \mathrm{NP} \quad=\text { Nilai Produk Olahan }(\mathrm{Rp} / \mathrm{Kg}) \\
& \mathrm{NBB} \quad=\text { Nilai bahan Baku }(\mathrm{Rp} / \mathrm{Kg}) \\
& \mathrm{NBP} \quad=\text { Nilai Bahan Penunjang }(\mathrm{Rp} / \mathrm{Kg})
\end{aligned}
$$

Setelah nilai tambah dari kedua produk diketahui maka akan dihitung nilai rasio nilai tambah dengan kriteria ujinya adalah sebagai berikut : jika rasio nilai tambah $>50 \%$ maka nilai tambah tergolong tinggi, sedangkan jika rasio nilai tambah $\leq 50 \%$ maka nilai tambah tergolong rendah (Aziz et al., 2017). 


\section{Pembahasan}

\subsection{Profil Usaha Tradisional Red Golden}

Usaha Pisang Sale Red Golden di Gampong Deyah Raya di dirikan oleh Bapak Husaini yang memulai usahanya dengan berbekal pengetahuan dan pengamatannya dengan melihat pisang sale yang dijual dipasaran. Muncul ide untuk membuka usaha pisang sale yang dapat menghasilkan produk yang berkualitas dengan beragam macam jenis pisang yang di sale seperti pisang sale, sale super, sale goreng dan sale som. Selain produk yang berbahan baku dari pisang, ada produk makanan lain yang bahan bakunya dari tepung yaitu sagun, nastar, timpan, dan dodol. Produk dikemas dengan kemasan yang dapat menjaga ketahanan dan daya simpan produk tersebut.

Usaha Pisang Sale Red Golden milik Bapak Husaini didirikan pada tahun 2014, dengan menyewa tempat sederhana sebagai rumah produksi pisang sale. Dengan menggunakan fasilitas seadanya dan modal $\pm \mathrm{Rp} 350.000$, usaha ini terus mengalami perkembangan dari waktu ke waktu sehingga bapak Husni sudah mempunyai pabrik milik sendiri dan sudah bisa membeli sebuah mobil untuk operasional para karyawan di pabrik dan akhirnya produk dari usaha beliau sudah mendapat izin dari DINKES KEMENKES untuk mempromosikan hasil produk pisang sale miliknya kepada masyarakat luas. Selain memiliki gudang milik sendiri, Bapak Husni sekarang sudah memiliki toko untuk pemasaran pisang sale dan nama toko tersebut adalah TRADISI ACEH yang beralamat di Jln. Khairil Anwar No. 64 Peunayong Banda Aceh. Konsumen yang membeli pisang sale tersebut bukan hanya dari wilayah Kota Banda Aceh saja melainkan ada yang dari luar daerah datang langsung ke pabrik untuk membeli dan melihat produksi pisang sale.

Untuk menghasilkan produk yang berkualitas sangat ditentukan oleh kualitas bahan baku yang digunakan, oleh karena itu usaha pisang sale Red Golden menggunakan pisang yang berkualitas bagus dan pisang tersebut di beli langsung dari pasar induk. Tidak hanya pisang saja yang berkualitas bagus melainkan bahan baku lainnya seperti tepung, coklat, keju, daun pisang juga harus tetap bagus dan higienis saat membuat kue (Habibah et al., 2006).

\subsection{Produk Pisang Sale yang di Produksi Usaha Tradisional Red Golden}

Proses pengolahan pisang sale pada Usaha Tradisional Red Golden, milik Pak Husni, memproduksi 2 jenis pisang sale yaitu pisang sale kering dan pisang sale basah. Bahan baku yang digunakan dalam tahapan proses pengolahan sale ini benar-benar diperhatikan kualitasnya, karena kondisi dari bahan baku akan menentukan kualitas dari pisang sale yang akan dihasilkan. 


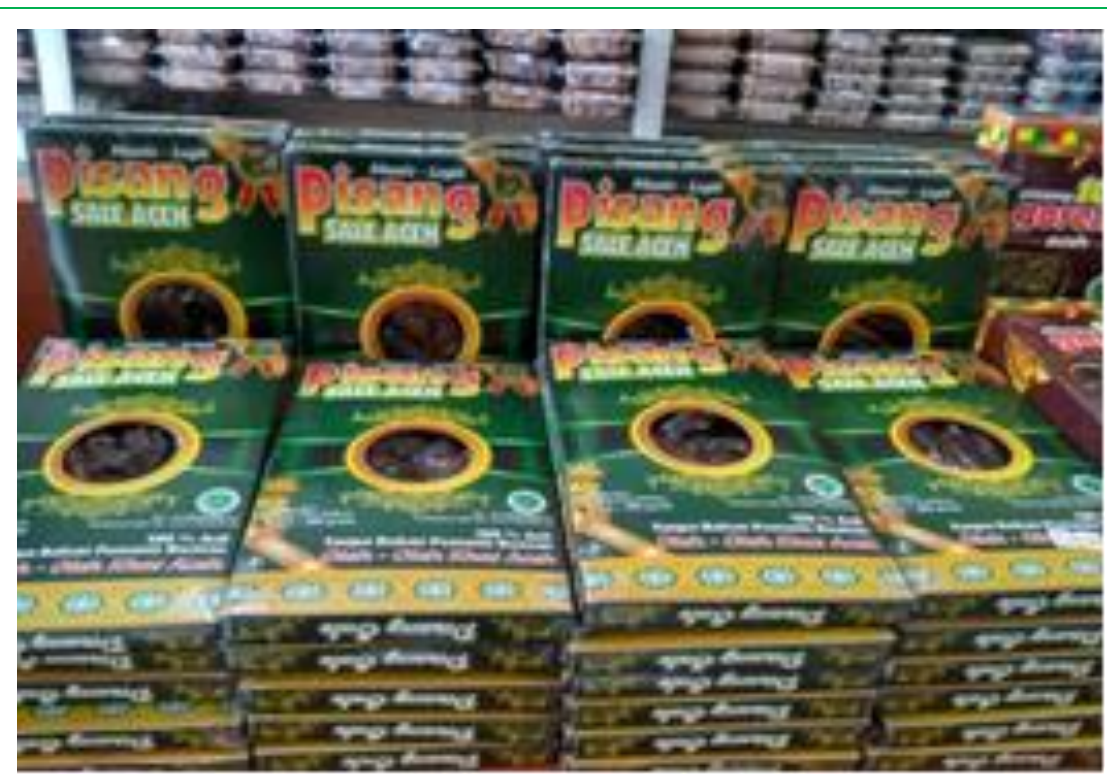

(a)

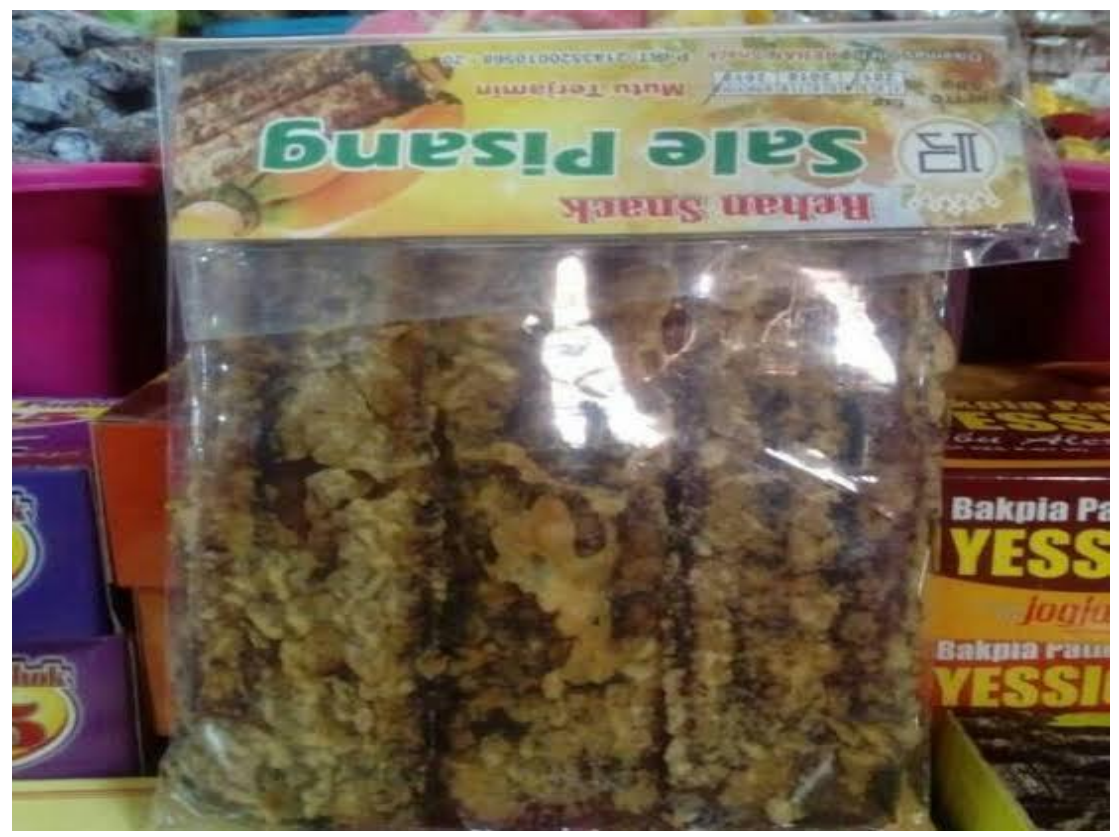

(b)

Gambar 1. (a) Pisang Sale Basah; (b) Pisang Sale Kering

Pengolahan pisang menjadi pisang sale yang dilakukan pada Usaha Tradisional Red Golden dalam satu kali produksi yaitu :

a. Produksi pisang sale basah satu periode selama 4 hari, dijual dengan harga Rp. 20.000,-/bungkus.

b. Pisang sale kering satu periode selama 2 hari, dijual dengan harga Rp. 10.000,-/bungkus. 


\subsection{Proses Pengolahan Pisang Sale}

Produk pisang sale yang diproduksi pada Usaha Tradisional Red Golden ada 2 jenis. Adapaun proses pengolahan pisang sale kedua produk tersebut adalah sebagai berikut :

\section{a. Proses Pengolahan Pisang Sale Basah}

1) Pemilihan bahan baku

Pisang yang digunakan adalah pisang yang matang dan tidak kelat. Hal ini bertujuan ketika proses pengasapan, pisang yang dipilih menjadi cepat masak dan tidak keras ketika dipipihkan.

2) Proses pengupasan

Pengupasan yang dilakukan pada proses pembuatan sale pisang ini bertujuan untuk mengambil bagian daging buah dari pisang. Pada proses pengupasan ini kulit pisang yang tak terpakai biasanya diberikan kepada hewan ternak, agar menghindari sampah terbuang percuma. bagian daging buah pisang yang sudah dikupas, di tumpuk pada satu wadah dan setelah penuh langsung dilakukan pengasapan

3) Proses pengasapan

Pisang yang sudah dikupas kemudian ditata dengan rapi di atas rak yang terbuat dari kawat besi dan di posisikan melintang diatas bara api yang jaraknya dengan pisang kurang lebih 2 meter. Hal ini bertujuan untuk mendapatkan pengasapan yang pas dan tidak terlalu hangus. Selain selama proses pengasapan tidak ada perlakuan tambahan seperti penambahan belerang. Proses pengasapan membutuhkan waktu 24 jam hingga pisang berubah coklat. Pada waktu pengasapan dilakukan proses pembalikan $1 \times 12$ jam agar pengasapan merata pada seluruh permukaan pisang.

\section{4). Proses pengemasan}

Proses pengemasan dilakukan agar pisang sale lebih tahan lama dan aman disimpan sebelum dipasarkan. Kemasan mempunyai peranan yang sangat penting dalam pemasaran. Selain harus berfungsi sebagai wadah dan pelindung isi produk, desain kemasan harus mampu menarik perhatian konsumen. Jenis plastik yang digunakan adalah Polypropylene (PP) dengan kapasitas 8 potong/plastik. Cara pengisian pisang ke dalam kemasan secara manual menggunakan sarung tangan dan kemasan ditutup menggunakan alat sealer. Pada kemasan sudah terdapat label yang menerangkan produk pisang yang dikemas. Pada label sudah terdapat keterangan komposisi nilai gizi dan label halal (Suyanti \& Supriyadi, 2008).

b. Proses Pengolahan Pisang Sale Kering

1) Pemilihan bahan baku

Pisang yang digunakan adalah pisang yang matang dan tidak kelat. Hal ini bertujuan ketika proses pengasapan, pisang yang dipilih menjadi cepat masak dan tidak keras ketika dipipihkan.

2) Proses pengupasan 
Pengupasan yang dilakukan pada proses pembuatan sale pisang ini bertujuan untuk mengambil bagian daging buah dari pisang. Pada proses pengupasan ini kulit pisang yang tak terpakai biasanya diberikan kepada hewan ternak, agar menghindari sampah terbuang percuma. bagian daging buah pisang yang sudah dikupas, di tumpuk meja kayu dan setelah penuh langsung dilakukan pengeringan.

3). Pengeringan

Pengeringan yang dilakukan pada proses pembuatan pisang sale ini bertujuan untuk menurunkan kadar air pisang, namun tujuan utama yang sebenarnya dari proses pengeringan ini adalah agar proses hidrolisis karbohidrat atau gula oleh enzim pemecah pati dapat berlangsung sehingga timbul rasa manis yang khas pada pisang sale. Pengeringan yang dilakukan pada umumnya dengan penjemuran selama 24 jam hingga pisang sale kering dan dengan oven selama 18 jam dengan suhu $50-70^{\circ} \mathrm{C}$. Apabila penjemuran yang dilakukan tidak sempurna proses pengeringannya karena terhambat oleh hujan, maka dilanjutkan proses pengeringan dengan oven sehingga dapat menjaga mutu dari sale pisang yang diproduksi agar tidak rusak karakteristiknya dan tidak berasa asam.

\section{4) Penggorengan}

Proses penggorengan yang dilakukan pada pembuatan pisang sale ini dilakukan yang bertujuan untuk mensterilisasi pisang yang telah dijemur yang memungkinkan dihinggapi oleh mikroorganisme, serangga dan kotoran lainnya yang menempel pada pisang pada saat dilakukan proses penjemuran. Pada proses penjemuran pisang adanya serangga seperti lalat buah yang hinggap ke pisang sudah umum terjadi, sehingga perlu penggorengan untuk mensterilisasi pisang dari kotoran dari hama lalat buah yang menyerang pisang pada saat penjemuran. Penggorengan yang berlangsung pada proses pembuatan pisang sale umumnya dilakukan dengan pecelupan ke dalam adonan tepung terigu sebelum dilakukan penggorengan. Pencelupan ke dalam adonan tepung terigu dilakukan bertujuan untuk membentuk karakteristik yang lebih renyah pada pisang sale. Komposisi pembuatan adonan umumnya hanya dibuat dari terigu, air dan bumbu-bumbu penyedap lainnya.

\section{5) Pengemasan}

Kemasan telah mengamankan dan mengawetkan segala jenis makanan dan minuman. Kemasan sangat mempengaruhi penampilan produk sehingga menarik konsumen. Kemasan juga sangat penting dalam menjaga keawetan dan higienitas produk dalam jangka waktu tertentu. Untuk produk pisang sale Kering jenis plastik yang digunakan adalah Polypropylene (PP) dengan kapasitas 8 potong/plastik. Cara pengisian pisang ke dalam kemasan secara manual menggunakan sarung tangan dan kemasan ditutup menggunakan alat sealer. Sedangkan untuk produk pisang sale basah menggunakan kertas karton berbentuk box dengan ukuruan 20 $\mathrm{cm}$ x $15 \mathrm{~cm}$ dimana pada kemasan sudah terdapat label yang menerangkan produk pisang yang dikemas. Pada label sudah terdapat keterangan komposisi nilai gizi dan label halal (Soekartawi, 2003).

Dari wawancara yang dilakukan oleh peneliti dengan pemilik Usaha Tradisional Red Golden, didapati usaha ini masih menggunakan alat-alat yang 
sederhana dan tidak berkapasitas tinggi atau belum menggunakan peralatan yang modern dalam proses pembuatan pisang sale.

Dengan demikian diketahui bahwaproses pengolahan pisang sale yang dilakukan didaerah penelitian masih tergolong sederhana.

\subsection{Nilai Tambah yang Diperoleh dari Pengolahan Pisang Sale}

Nilai tambah merupakan pertambahan nilai yang terjadi karena suatu komoditi mengalami proses pengolahan, pengangkutan, dan penyimpanan dalam suatu proses produksi (penggunaan/pemberian input fungsional). Besarnya nilai tambah dipengaruhi oleh faktor teknis dan faktor nonteknis. Informasi yang diperoleh dari hasil analisis nilai tambah adalah besarnya nilai tambah, rasio nilai tambah dan balas jasa yang diterima oleh pemilik-pemilik faktor produksi (Aziz et al., 2017).

Metode analisis yang digunakan untuk mengetahui nilai tambah yang diperoleh dari pengolahan pisang sehingga menjadi pisang sale adalah metode perhitungan nilai tambah model Hayami. Namun, penulis hanya mengambil rumus dari metode (Hayami, 1987) tersebut untuk menghitung besarnya nilai tambah dan rasio nilai tambah yang dihasilkan. Perhitungan nilai tambah yang dilakukan pada proses pengolahan pisang dengan tujuan untuk mengukur besarnya nilai tambah yang terjadi akibat adanya proses pengolahan pisang menjadi pisang sale yang siap dipasarkan.

Nilai tambah diperoleh dari proses pengolahan pisang sampai menjadi produk olahan. Output (produk olahan) yang dihasilkan pada proses ini adalah pisang sale. Hasil yang didapat di daerah penelitian berupa pisang sale yang dibungkus dengan menggunakan plastik. Selain ukuran plastik yang berbeda, bobot output per bungkusnya juga beragam. Ada yang bobotnya pisang sale basah dengan kotak berat 280 gram untuk pisang sale kering dalam plastik dengan berat 200 gram.

\subsubsection{Input dan Output}

Input adalah penjumlahan bahan baku yang digunakan selama satu periode produksi untuk diproses sampai menjadi pisang sale dan dikur dengan satuan $\mathrm{Kg}$ bahan baku. Output adalah penjumlahan produk/output yang dihasilkan selama satu periode produksi yang diukur dalam satuan $\mathrm{Kg}$ produk. Rata-rata penggunaan bahan baku (input) dan Output yang dihasilkan di daerah penelitian dapat dilihat pada Tabel 1.

Tabel 1. Penggunaan Input dan Output yang dihasilkan di Usaha Tradisional Red Golden Tahun 2019

\begin{tabular}{lcccc}
\hline \multirow{2}{*}{ Uraian } & \multicolumn{2}{c}{ Pisang Sale Basah } & \multicolumn{2}{c}{ Pisang Sale Kering } \\
\cline { 2 - 5 } & Input (Kg) & output $(\mathrm{Kg})$ & Input $(\mathrm{Kg})$ & ouput $(\mathrm{Kg})$ \\
\hline Per Hari & 30 & 25 & 30 & 25 \\
\hline Per Minggu & 60 & 50 & 90 & 75 \\
\hline Per Bulan & 240 & 200 & 380 & 300 \\
\hline Per Tahun & 2.880 & 2.400 & 4.320 & 3.600 \\
\hline
\end{tabular}

Sumber : Analisis Data Primer (2019)

Dari Tabel 1. dapat dilihat bahwa, jumlah output yang dihasilkan selama satu periode produksi (per hari) adalah sebesar $25 \mathrm{Kg}$ pisang sale baik pisang sale basah maupun pisang sale kering, dengan mengolah pisang sebanyak $30 \mathrm{Kg}$. 
Sehingga faktor konversi yang didapat adalah sebesar 0.83. Nilai konversi ini menunjukkan bahwa setiap pengolahan $1 \mathrm{Kg}$ pisang akan menghasilkan 0,83 $\mathrm{kg}$ pisang sale baik pisang sale basah maupun produk pisang sale kering. Faktor konversi merupakan perbandingan penggunaan bahan baku dengan output yang dihasilkan (konversi antar input dan output).

\subsubsection{Biaya Bahan Penunjang (Sumbangan Input Lain)}

Dalam proses pembuatan pisang sale bahan bakunya adalah pisang. Selain bahan baku, proses pembuatan pisang sale juga membutuhkan bahan- bahan penunjang (input lain) seperti gula, minyak goreng, vanili, daun, air, plastik dan sebagainya. Secara rinci biaya bahan penunjang (sumbangan input lain) pada pembuatan pisang sale dapat dilihat pada Tabel 2.

Tabel 2. Bahan penunjang yang digunakan pada pengolahan pisang sale:

\begin{tabular}{cccc}
\hline No & Uraian & Sale Basah (Rp) & Pisang Sale Kering(Rp) \\
\hline 1 & Gula & 15.000 & - \\
\hline 2 & Daun Pisang & 2.000 & 2.000 \\
\hline 3 & Air & 3.000 & 3.000 \\
\hline 4 & Plastik & 3.000 & 3.000 \\
\hline 5 & Vanili & 1.000 & 1.000 \\
\hline 6 & Kayu & 10.000 & - \\
\hline 7 & Bensin & 15.000 & - \\
\hline 8 & Tepung & - & 6.000 \\
\hline 9 & M. Goreng & - & 1.000 \\
\hline 10 & Garam & - & 23.000 \\
\hline Total & & 49.000 &
\end{tabular}

Dari Tabel 2 diatas diketahui bahwa biaya penunjang yang paling besar adalah bahan bakar yaitu gula dan bensin Rp. 15.000,- , sedangkan biaya bahan penunjang yang paling sedikit adalah garam dan vanili yaitu sebesar Rp. 1.000,-Total biaya keseluruhan biaya penunjang untuk pisang sale basah yaitu Rp. 49.000,- dan untuk pisang sale kering Rp. 23.000,--

\subsubsection{Harga Input, Harga Output, Nilai Output, Nilai Tambah dan Rasio Nilai Tambah.}

Secara rinci harga input, harga output, nilai output, nilai tambah dan rasio nilai tambah pisang sale dapat dilihat pada Tabel 3.

Tabel 3. Harga Input, Harga Output, Nilai Output, Nilai Tambah dan Rasio Nilai Tambah pisang sale kering dan pisang sale kering di Usaha Tradisional Red Golden Tahun 2019

\begin{tabular}{cccc}
\hline No & Uraian & Pisang sale kering & Pisang sale basah \\
\cline { 3 - 4 } & & Nilai $(\mathrm{Rp} / \mathrm{Kg})$ & Nilai $(\mathrm{Rp} / \mathrm{Kg})$ \\
\hline 1 & Harga Input & 6.000 & 6.000 \\
\hline 2 & Harga Output & 50.000 & 100.000 \\
\hline 3 & Nilai Output & 41.500 & 83.000 \\
\hline 4 & Nilai Tambah & 12.500 & 28.000 \\
\hline 5 & Rasio Nilai Tambah & $30,1 \%$ & $33,7 \%$ \\
\hline
\end{tabular}

Sumber : Analisis Data Primer (2019)

Rata-rata harga input (bahan baku) pada usaha tradisional Red Golden adalah sebesar Rp. 6.000. Harga output pisang sale basah di daerah penelitian 
adalah sebesar Rp. 100.000/Kg. Nilai outputnya adalah Rp. 83.000/Kg. Sedangkan untuk pisang sale kering Rp. $41.500 / \mathrm{Kg}$. Nilai outputnya adalah Rp. 36.000. Nilai output pada pengolahan pisang menjadi pisang sale ini diperoleh dari hasil perkalian antara faktor konversi dengan harga output $(\mathrm{Rp} / \mathrm{Kg})$.

Besarnya nilai tambah yang didapat dari perhitungan sejalan dengan besarnya rasio nilai tambah terhadap nilai outputnya. Rasio nilai tambah ini didapat dari pembagian antara nilai tambah dengan nilai output yang dinyatakan dalam persen (\%). Rasio nilai tambah ini menunjukkan persentase nilai tambah dari nilai output, artinya jika rasio nilai tambah $>50 \%$ maka nilai tambah lebih besar dari pada nilai output dan nilai tambah tergolong tinggi, sedangkan jika rasio nilai tambah $\leq 50 \%$, maka nilai tambah yang dihasilkan lebih kecil dari nilai outputnya dan nilai tambah tergolong rendah.

Secara matematis rasio nilai tambah pengolahan pisang sale basah yaitu sebagai berikut :

Rasio Nilai Tambah Pisang Sale Kering

$=\frac{12.500}{41.500} \times 100 \%=30,1 \%$

Rasio Nilai Tambah Pisang Sale Basah

$=\frac{28.000}{83.000} \times 100 \%=33,7 \%$

Dengan demikian dapat dinyatakan bahwa nilai tambah yang dihasilkan dari proses pengolahan pisang menjadi pisang sale pada skala industri rumah tangga pada Usaha Tradisional Red Golden masih tergolong rendah. Hal tersebut dikarenakan nilai rasionya lebih kecil dari $50 \%$.

\section{Penutup}

Proses pengolahan pisang menjadi pisang sale pada skala industri rumah tangga di daerah penelitian masih tergolong sederhana. Selain itu, nilai tambah (value added) yang dihasilkan dari pengolahan pisang menjadi pisang sale pada skala industri rumah tangga di daerah penelitian masih rendah. Dan masih terdapat beberapa kendala dalam usaha pengolahan pisang sale pada skala industri rumah tangga pada Usaha Tradisional Red Golden yaitu proses pengolahan yang masih menggunakan alat yang sederhana, keterbatasan modal dan pemasaran yang masih terbatas.

Diharapkan pengusaha dapat mengembangkan variasi rasa dari pisang sale, sehingga konsumen tidak merasa bosan dengan produk pisang sale yang ditawarkan.

Disarankan agar usaha pengolahan pisang sale skala rumah tangga lebih mengembangkan dan meningkatkan usahanya menjadi skala industri kecil. Untuk meningkatkan kualitas dan jaminan ketersediaan bahan baku secara lokal, pemerintah diharapkan membina petani pisang untuk bekerja sama dengan usaha pengolahan pisang melalui pola kemitraan.

\section{Daftar Pustaka}

Aziz, A., Miftah, H., \& Arsyad, A. (2017). Analisis Nilai Tambah dan Marjin 
Pemasaran Pisang Menjadi Olahan Pisang (Studi Kasus Pada Industri Kecil "SRIKANDI") di Kelurahan Dangdeur Kecamatan Subang Kabupaten Subang Jawa Barat. Jurnal Agribisains. https://doi.org/10.30997/jagi.v3i1.1030

Habibah, U., Fachraniah, Z., \& Fona, E. (2006). Penggunaan Metode Akselerasi pada Penentuan Umur Simpan Pisang Sale dengan Pengemas yang Berbeda-beda. Jurnal Reaksi (Journal of Science and Technology) Jurusan Teknik Kimia Politeknik Negeri Lhokseumawe.

Hapsoro, D., \& Yusnita. (2018). Kultur Jaringan Teori dan Praktik. ANDI.

Hasanah, Uswatun, \& Dkk. (2015). Analisis Nilai Tambah Agroindustri Sale Pisang di Kabupaten Kabumen. Jurnal Ilmu Pertanian, 18(3), 141-149.

Hayami, Y. (1987). Agricultural marketing and processing in upland java, a perspective from Sunda Village. CGPRT Center.

Mainura. (2014). Analisis Nilai Tambah Dan Sistem Pemasaran Pisang Sale Di Kecamatan Langkahan Kabupaten Aceh Utara. Universitas Syiah Kuala, Banda Aceh.

Soekartawi. (2003). Agribisnis Teori dan Aplikasinya. PT. Raja Grafindo Persada.

Suyanti, S., \& Supriyadi, A. (2008). Pisang Budidaya, Pengolahan dan prospek Pasar. Jurnal Hasil Penelitian Program Study Keteknikan Pertanian. 